\title{
METODE IMAM ASY-SYAUKANI DALAM MENYUSUN KITAB NAILUL AUTAR SYARH MUNTAQAL-AKHBAR
}

\author{
Fauzi Rizal \\ Institut Agama Islam Negeri Padangsidimpuan \\ E-mail: fauzi.rizal16@gmail.com
}

\begin{abstract}
Abstrak
Tulisan ini bertujuan untuk mendeskripsikan metode Imam AsySyaukani dalam menyusun kitab Nailul Autar Syarh Muntaqal-Akhbar. Kitab Nailul Authar adalah kitab syarh dari dari kitab hadis hukum yang dihimpun oleh ibnu Taimiyan "al-Muntaqa" yang terdiri dari 5029 hadis, kemudian disyarh oleh Asy-Syaukani menjadi 8 juz, masing-masing setelal 380 halaman, hingga menjadi 3040 halaman. Oleh karena itu penulis mencoba untuk memberikan gambaran terhadap buku kitab yang dimaksud.
\end{abstract}

\begin{abstract}
This article aims to describe the method of Imam Asy-Syaukani in compiling the book Nailul Autar Syarh Muntaqal-Akhbar. Kitab Nailul Authar is a book of shar from the book of legal hadith compiled by ibn Taimiyan "al-Muntaqa" consisting of 5029 traditions, then disyarh by Asy-Syaukani to 8 juz, each of 380 pages, up to 3040 pages. Therefore the author tries to give a picture of the intended book.
\end{abstract}

Kata Kunci: Imam Asy-Syaukani, Kitab Nailul Autar Syarh MuntaqalAkhbar. 


\section{Fauzi Rizal}

\section{Pendahuluan}

Para ulama hadis telah banyak memberikan kontribusi besar dalam rangka menjaga kemurnian hadis dengan menetapkan kaedah-kaedah umum untuk mengetahui hadis yang maqbul (diterima) dan hadis yang mardud (ditolak). Kaidah-kaidah dasar tersebut telah dibukukan dan menjadi suatu cabang ilmu hadis yaitu ilmu musthalah hadis.

Syarah merupakan penjelasan terhadap hadis Rasulullah saw berdasarkan ijtihad ulama sesuai dengan ilmu yang dimilikinya. Oleh sebab itu seorang ulama memiliki metode berbeda dengan ulama lainnya dalam mensyarah hadis. Hal ini disebabkan karena latar belakang keilmuan yang berbeda atau karena mazhab yang berbeda sehingga mempengaruhi terhadap syarah yang dilakukan.

Kitab Nailul Authar adalah kitab syarh dari dari kitab hadis hukum yang dihimpun oleh Ibnu Taimiyah "al-Muntaqa" yang terdiri dari 5029 hadis, kemudian disyarh oleh Asy-Syaukani menjadi 8 juz, masing-masing setelal 380 halaman, hingga menjadi 3040 halaman. Oleh karena itu,tulisan ini untuk memberikan gambaran kitab yang dimaksud.

\section{Biografi Iman asy-Syaukani}

Nama lengkapnya adalah Muhammad bin Ali bin Muhammad bin Abdullah Asy-Syaukani Ash-Shan'an. Julukannya adalah Imam AsySyaukani yang dinisbahkan kepada wilayah Syaukan, merupakan salah satu suku Khan yang terletak di antara dengan masafah. Sedangkan asShan'ani dinisbahkan kepada kota Shan'a kota tempat ayahnya dilahirkan dan dibesarkan. ${ }^{1}$

la dilahirkan pada hari Senin tanggal 28 Dzulqi'dah $1173 \mathrm{H}$, kemudian ia besar di Shan'a, Yaman. la berasal dari keluarga yang menganut mazhab Syiah Zaidiyah, ayahnya adalah seorang hakim. Kemudian ia beralih kepada mazhab Sunni dan menyerukan untuk kembali kepada sumber tekstual dari Alquran dan Hadits. Beliau tumbuh di bawah asuhan ayahandanya dalam lingkungan yang penuh dengan keluhuran

1Muahammad Subhi bin Hasan Hallaq, Nailul Authar min Asrar Muntaqa al-Akhbar (Riadh: Dar Ibn Taimiyah, 1427 H), hlm. 27. 
budi dan kesucian jiwa. Beliau belajar Alquran di bawah asuhan beberapa guru dan dikhatamkan di hadapan al-Faqih Hasan bin Abdullah al-Habi dan beliau perdalam kepada para masyayikh Alquran di Shan'a. Kemudian beliau menghafal berbagai matan dalam berbagai disiplin ilmu, seperti: alAzhar oleh al- Imam al-Mahdi, Mukhthasar Faraid oleh al-Usaifiri, Malhatul Harm, al-Kafiyah asy-Syafiyah oleh Ibnul Hajib, at-Tahzib oleh at-Tifazani, at-TalkhisfiUl-mal-Balaghah oleh al-Qazwaini, al-Ghayah oleh Ibnu alImam, Mamhumah al-Jazarif al-Qira'ah, Mamhumah al-Jazzar fl al- 'Arud, Adab al- Bahs wal Munazarah oleh al-Imam al-`Adud.

Pada awal belajarnya, beliau banyak menelaah kitab-kitab tarikh dan adab. Kemudian beliau menempuh perjalanan mencari riwayat hadis dengan sama dan talaqqi kepada para guru-guru hadis hingga beliau mencapai derajat imamah dalam ilmu hadis.

la menghafal Alqur'an dan sejumlah ringkasan matan dari berbagai disiplin ilmu semenjak kecil. Metode dan mazhabnya diterima luas di Yaman, kemudian sampai di India lewat seorang muridnya yang bernama Abd al-Haq al-Hindi. ia telah menjadi seorang mufti (pemberi fatwa) pada usia dua puluh tahun. Pada tahun $1209 \mathrm{H}$ hakim besar Yaman Yahya bin Salih asy-Syajri as-Sahuli ${ }^{2}$ meninggal dunia dan posisinya digantikan oleh Imam Asy-Syaukani pada saat usianya 36 tahun, hingga wafatnya pada tahun $1250 \mathrm{H} / 1834 \mathrm{M}$.

Imam Asy-Syaukani wafat di Shan'a pada bulan Jumadil Akhir tahun $1250 \mathrm{H} / 1834 \mathrm{M}$ pada umur 76 tahun 6 bulan, tepatnya malam Rabu. la dimakamkan di pemakaman Khuzaimah di Shan'a, dan disalatkan di Masjid Jami' Kabir. ${ }^{3}$

Aqidah beliau adalah aqidah salaf yang menetapkan sifat-sifat Allah yang datang dalam Kitab dan Sunnah tanpa mentakwil dan mentahrif. Beliau menulis risalah dalam aqidah yang berjudul at-Tuhaf bi Mazahib asSalaf.

2Muahammad Subhi bin Hasan Hallaq, Nailul Authar..., hlm.30.

3Muahammad Subhi bin Hasan Hallaq, Nailul Authar ..., hlm. 56. 
Fauzi Rizal

Karya Tulis

Imam Asy-Syaukani memiliki banyak karya-karya tulis, mayoritas kitab tersebut telah tersebar di masa hidupnya. Terdapat 278 buku yang masih berbentuk manuskrip, sedangkan yang tercetak mencapai 38 judul.

Di antara karyanya yang paling terkenal adalah:

1. Tuhfatud Dzakiriin Syarah Iddatul Hisnil Hushain.

2. Syarh Sudur fi Rafiil Qubur.

3. Risalah fi Haddi al-Safari Yajibu Ma ahu Qajrus salati

4. Risalah fi Hukmi al-Thalaq al-Bidh 'i hal Yaqa 'u am la

5. Ittihaful Mahra fi al-Kalam 'alahadisi la 'Adwa a wa laTayrah

6. Risalah al-Bughyah fi Masalati al-Ru'yati

7. Al- Tasykik 'ala al-Tafkik wa Irsyadul Ghabiyyi illa Ma'abi Ahlil Bayti fi Suhubi al-Nabiyyi

8. Al-Bahsul al-Musfir'an Tahrim Kullu Muskirin

9. Risalah fi Hukmi al-Tas ir

10. Al-Tau«ih fi Tawaturi ma ja fil al-Mahdi al-Muntasary wa al-Dajjali wa al-Masih.

Di samping itu, karya-karyanya yang terkenal adalah: ${ }^{4}$

1. Tafsir

Fathul Qadir Al-Jami Bayana Fanay Al-Riwayah wa Al-Dirayah.

2. Fiqih

Al-Saylu Al-Jarar Al-Muttadafiq 'Ala Hadaiqal Al-Azhar, yaitu syarah AlAzhar fiFiqhi 'Alil Bayati.

3. Hadis

Nailul Al-Authar Syarh Al-Muntaqa Al-Akbar.4

\section{Guru dan Murid}

Imam Asy-Syaukan ${ }^{3}$ dibesarkan ditanah San'a dan menimba ilmu bersama ayahandanya. Beliau sewaktu menjadi seorang pelajar selalu belajar dengan sungguh-sungguh. Selain berguru kepada ayahandanya dan kepada ulama-ulama lain, beliau juga sempat belajar Alquran bersama

4Muhammad Subhi bin Hasan Hallaq, Nailul Authar..., hlm. 38-39. 
teman-temannya dan sempat menyelesaikannya bersama Imam Faqih Hasan bin Abdullah. Kemudian beliau perdalam ilmu Alquran dengan ulama-ulama yang menguasai tafsir-tafsir Alquran pada masa itu di San'a. Guru-gurunya diantaranya:

1. Ayahandanya untuk belajar Syarh al-Azhar dan Syarh Mukhtajar alHariri.

As-Sayid al-Allamah Abdurrahman bin Qasim al-Madain², beliau belajar kepadanya Syarh al-Azhar.

2. Al-Allamah Ahmad bin Amir al-Hadai, beliau belajar kepadanya Syarh alAzhar.

3. Al-Allamah Ahmad bin Muhammad al-Harazi, beliau berguru kepadanya selama 13 tahun, mengambil ilmu fikih, mengulang-ulang Syarh al-Azhar dan Hasyiyahnya, serta belajar Bayan Ibnu Musaffar dan Syarh anNasiri dan Hasyiyahnya.

4. As Sayyid al-Allamah Ismail bin Hasan, beliau belajar kepadanya alMalhah dan syarahnya.

5. Al-Allamah Abdullah bin Ismail as-Sahmi, beliau belajar kepadanya Qawa idul I'rab dan syarahnya serta Syarh al-Khubaiji alaal-Kafiyah dan syarahnya.

6. Al-Allamah al-Qasim bin Yahya al-Khaulani, beliau belajar kepadanya Syarh as-Sayyid al-Mufti alaal-Kafiyah, Syarh asy-Syafiyah li Luthfillah al-Dhiyas, dan Syarh ar-Ridha 'alaal-Kafiyah.

7. As-Sayyid al-Allamah Abdullah bin Husain, beliau belajar kepanya Syarh al-Fami 'alaal-Kafiyah.

8. Al-Allamah Hasan bin Isma`il al-Maghribi, beliau belajar kepadanya Syarh al-Adhud alaal-Mukhtajar serta mendengarkan darinya Sunan Abu Dawud dan Ma'limus Sunan.

9. As-Sayyid al-Imam Abdul Qadir bin Ahmad, beliau belajar kepanya Jam'ul Jaw \pm mi' lil Muhalili dan Bahruz Zakhkhar serta mendengarkan darinya sahih Muslim, Sunan TirmiCi,Sunan Nasa'i, Sunan Ibnu Majah, Muwatta' Malik, dan Syifa Qadi 'lyad

10. Hadi bin Husain al-Qarani, beliau belajar kepadanya Syarh alJazariyyah. 


\section{Fauzi Rizal}

11. Abdurrahman bin Hasan al-Akwa, beliau belajar kepadanya Syifa alAmir Husain.

12. Ali bin Ibrahim bin Ahmad bin Amir, beliau mendengarkan darinya sahih al-Bukhari dari awal dan hingga ahir.

Beliau juga mempunyai 87 murid di antaranya:

1. Putra beliau yaitu: Syekh Ali bin Muhammad (1229-1281 H/1813-1864 M)yang waktu itu termasuk anak yang salih dan alim berbagai cabang ilmu beliau kuasai dan jarang sekali anak seusia beliau mempunyai ilmu setingkat itu.

2. Sayid Ahmad bin Ali bin Muhsin bin Ali bin Imam al-Mutawakkil 'Ala Allah Ismail bin Qasim as-San'an³ (1151- 1222 H/1739-1807 M)

3. Ahmad bin Nasr al-Kibsi (1209-1271 H/1794-1854 M)

4. Ahmad bin Husain al-Wizn al-San'an³ (1176-1238 H/1762-1822 M)

5. Ahmad bin Lutf al-Bari bin Ahmad bin 'Abd al-Qadr al-Ward (1191-1282 $\mathrm{H} / 1777-1865 \mathrm{M})$

6. Ahmad bin Muhammad bin Ahmad bin Muthahr al-Qabili al-Jauzi alZamari (1158 H/1745 M) masih banyak lagi yang lainnya. ${ }^{5}$

Semua murid-muridnya banyak menyerap ilmu yang diajarkan olehlmam Asy-Syaukani, mulai dari ilmu fiqih, hadis, filsafat dan lainlain.Murid-muridnya banyak yang menjadi ulama-ulama besar.

\section{Kitab Nailul Authar}

1. Manhaj Imam Asy-Syaukani dalam mensyarah al-Muntaqa, yaitu:

a. Menjelaskan keadaan hadis, menjelaskan keganjilan-keganjilan, dan tidak menjelaskan secara mendetail.

b. Bab-bab tertentu yang belum disebutkan oleh penulis al-Muntaqa (Ibnu Taimiyah) dijelaskan beliau.

c. Tidak menjelaskan keadaan perawi (tidak menjelaskan secara detail tentang perawi) sebagaimana dalam kitab rujukannya.

5Muhammad Subhi bin Hasan Hallaq, Nailul Authar..... hlm. 38-39. 
d. Melakukan hal yang sama seperti yang dilakukan oleh ibnu Taimiyah baik tentang syarh hadis, keputusan hukum, bahkan komentar-komentar. Ketika berbicara tanpa berdasarkan dalil maka beliau diam tanpa komentar.

e. Beliau termasuk orang yang ketat (mutasyaddid) sama seperti gurunya Abdul Qadir bin Ahmad.

2. Sistematika penyusunan Kitab Nailul Authar.

a. Bahwa dalam kitab ini dimuat sekitar 44 kitab dan sekitar 1034 bab yang ditulis dalam 8 jilid dan 3040-3050 halaman secara keseluruhan.

b. Hadis yang dimuat dalam kitab ini tidak disebutkan dengan lengkap sanad-sanadnya.

Contoh:

1. Kitab Taharah al-Ma'i al-Mutawada'a bih

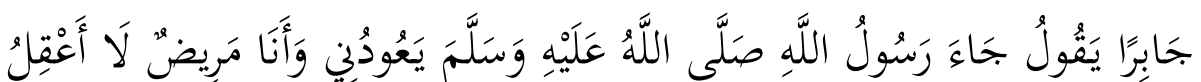

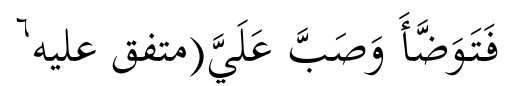

Sementara dalam kitab sanad lengkapnya sebagaimana tersebut di bawah ini dan matannya juga tidak secara lengkap terdapat matan dengan lengkap, oleh Imam al-Bukhari menambah kata 7 وَضُوِئِن.

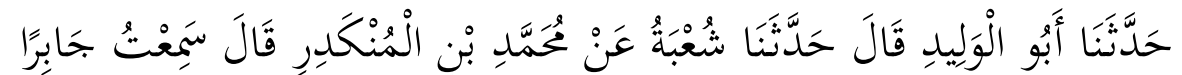

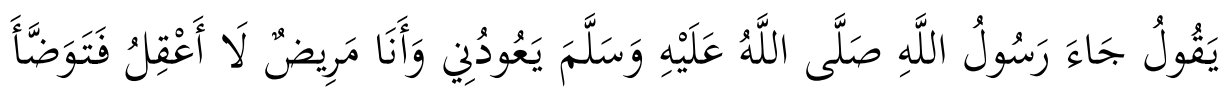

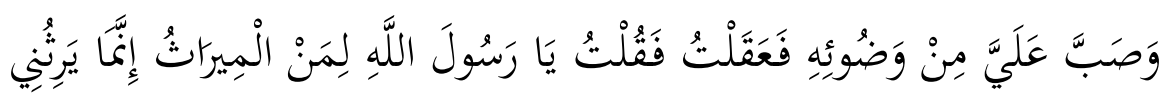

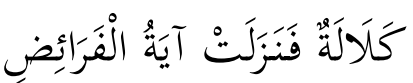

6Muhammad bin Ali bin Muhammad al-Syaukani, Nailul Authar Syarh Muntaqa alAkhbar, Juz I (tp. Maktabah wa mathba'ah Musthafa al-Babi al-Halabi wa Auladuh, t.th), hlm.29.

7al-Syaukani, Nailul Authar...., hlm. 30. 
"Telah menceritakan kepada kami Abu Al Walid berkata, telah menceritakan kepada kami Syu'bah dari Muhammad bin Al Munkadir berkata, "Aku mendengar Jabir berkata, "Rasulullah shallallahu 'alaihi wasallam datang menjenguk saat aku sedang sakit yang mengakibatkan aku tidak sadar. Nabi shallallahu 'alaihi wasallam lalu berwudlu dan menyiramkan sisa air wudlunya hingga aku pun sadar. Aku lalu bertanya, 'Wahai Rasulullah, untuk siapakah warisan itu? Sebab aku tidak mewariskan kalalah (tidak punya anak)?' maka turunlah ayat tentang waris."8

2. Pada kitab Libas: bab haramnya pakaian sutera dan emas bagi laki-laki.

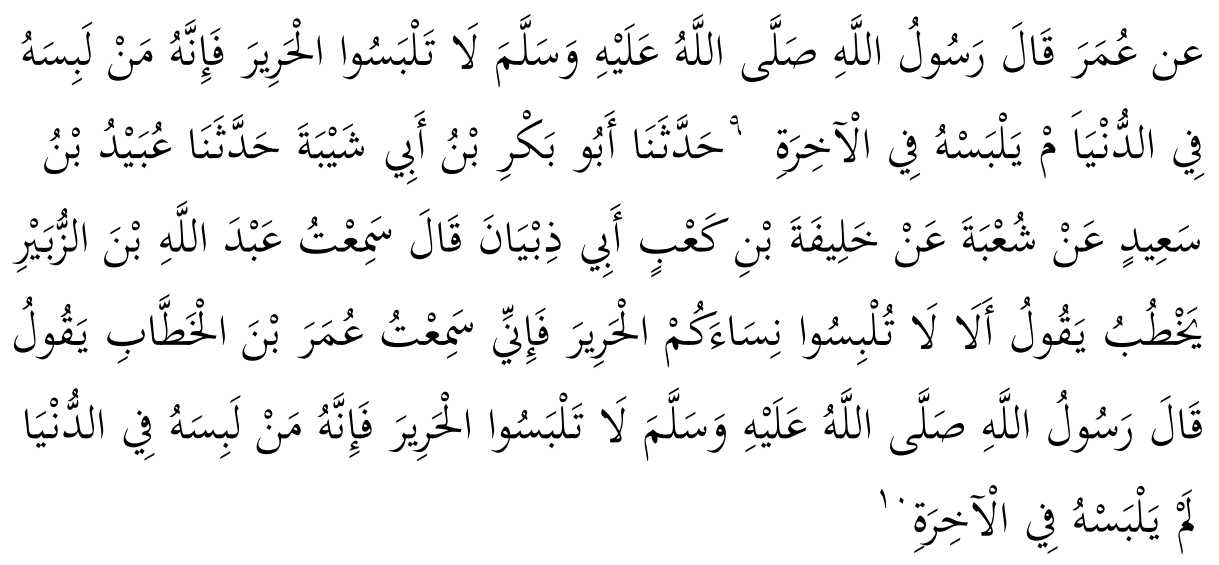

"Telah menceritakan kepada kami Abu Bakr bin Abu Syaibah; Telah menceritakan kepada kami 'Ubaid bin Sa'id dari Syu'bah

8Lidwa Pustala i-Software, Kitab Sembilan Imam (software, Kitab Imam al-Bukhari no.187), lihat. Abi 'Abdillah Muhammad bin Ismail al-Bukhari, al-Jami' as-Sahih alMusnad min ad ${ }^{3}$ Rasulullah Salla Allahu 'alaihi wa sallama wa Sunanihi wa Ayyamihi (AlQahirah: Ma ba'ah alafiyah wa Maktabatuha, $1400 \mathrm{H}$ ), dalam bab ke 44 Subbi anNabialla Allahu 'alaihi wa sallama Wu«u'ahu 'ala Mugma 'Alaihi hadis nomor 193.

9al-Syaukan³, Nailul Authar.. juz II., hlm.91.

10 lbid., Kitab Muslim no. 3856, lihat Abi Husein Muslim bin Hajjaj Ibn Muslim alQusyairi an-Naisaburi, Jami' as-Sahih, Nomor Hadis 22 dalam bab Tahrim Isri'mal Ina'in az-Zahabi wa al-Fidati 'Ala Rijal mwa an-Nisa', hlm.140. 
dari Khalifah bin Ka'b Abu Dzibyan ia berkata; Aku mendengar 'Abdullah bin Az Zubair berkhutbah, dia berkata; "Ingatlah, janganlah kalian memberikan kepada istri-istri kalian pakaian sutera. Karena aku mendengar Umar bin Khatthab berkata; Rasulullah shallallahu 'alaihi wasallam bersabda: "Janganlah kalian memakai kain sutera, karena barang siapa yang memakainya ketika di dunia, niscaya dia tidak akan memakainya ketika di akhirat kelak."

3. Pada setiap hadis, dijelaskan maksud hadis, keadaan para perawi dalam pandangan ulama al-Jarh wa at-Ta'dil.

Contoh:

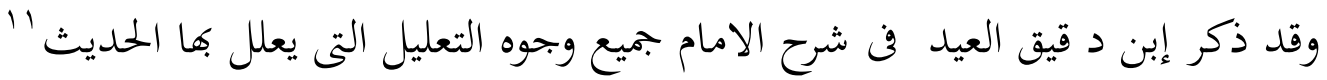

Sebagaimana telah disebutkan oleh Ibnu Daqiq al-'Id dalam syarh para imam, bahwa hadis tersebut mu'allal ${ }^{12}$, karena hadisnya disamarkan. Malah menurut Imam asy-Syafi'i ada sanad yang tidak terdeteksi, ${ }^{13}$ Ibnu Hajar (majhul la ya'rif), sementara hadis dari jalur dari Tabrani disebutkan dalam kitabnya al-Kabir dan AdDaruquthni serta Hakim, al-Hafiz menyebutkan sanadnya hasan ${ }^{14}$ dan sudah keluar dari kekhawatiran dari tadlis. ${ }^{15}$

11al-Syaukani, Nailul Authar..., hlm.24-26.

${ }^{12}$ Hadis mu'allal menurut para ahli hadis adalah hadis yang di dalamnya terdapat cacat yang tersembunyi, namun dari sisi lahiriyahnya cacat tersebut tidak Nampak karena sudah memenuhi syarat-syarat hadis maqbul, lihat Muhammad Alawi al-Maliki, IImu Ushul Hadis, terj. Adnan Qohar (Yogyakarta: Pustaka Pelajar, 2009), hIm. 121.

13al-Syaukani, Nailul Authar...hlm. 25.

${ }^{14}$ Hadis hasan ialah setiap sanad yang diriwayatkan dan tidak terdapat pada sanadnya perawi yang pendusta, dan hadis tersebut tidak syaz serta diriwayatkan melalui jalan yang lain. Lihat, Nawir Yuslem, Ulumul Hadis (Tp: PT. Mutiara Sumber Widya, 2001), hlm.228.

15 Tadlis adalah hadis yang disampaikan oleh seorang perawi dari orang semasa dengannya dan ia bertemu sendiri dengan orang itu, ia tidak mendengar langsung hadis tersebut, atau ia tidak pernah bertemu namun ia mengambil hadis darinya. Lihat Subhi As- 


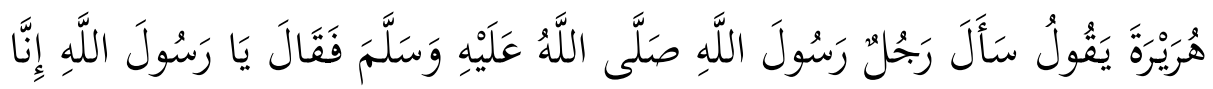

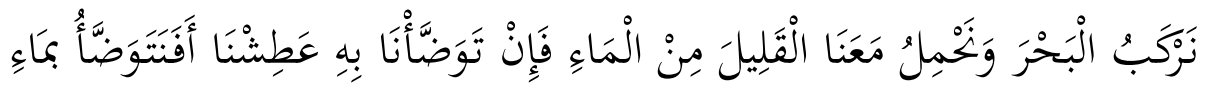

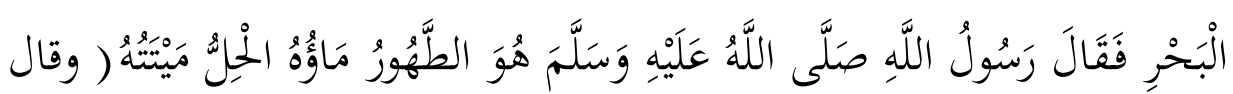

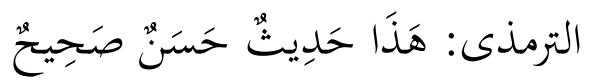

Hadis ini diriwayatkan juga oleh Ibn Khuzaimah, Ibnu Hibban, alHakim dalam Mustadraknya, ad-Daruquthni dan Baihaqi dalamsunanmereka, dan Ibnu Syaibah. Secara lengkap sanadnya dikutip dari kitab Sunan Tirmizi ${ }^{3}$ dengan terjadi sedikit perbedaan kata بَمَاِ الْبَحْرِ baik dari kitab al-Muntaqa ${ }^{16}$ maupun dari kitab nailul Autar17, sementara dalam kitab sunan Tirmizi مِنْ الْبَحْرِ sebagai berikut:

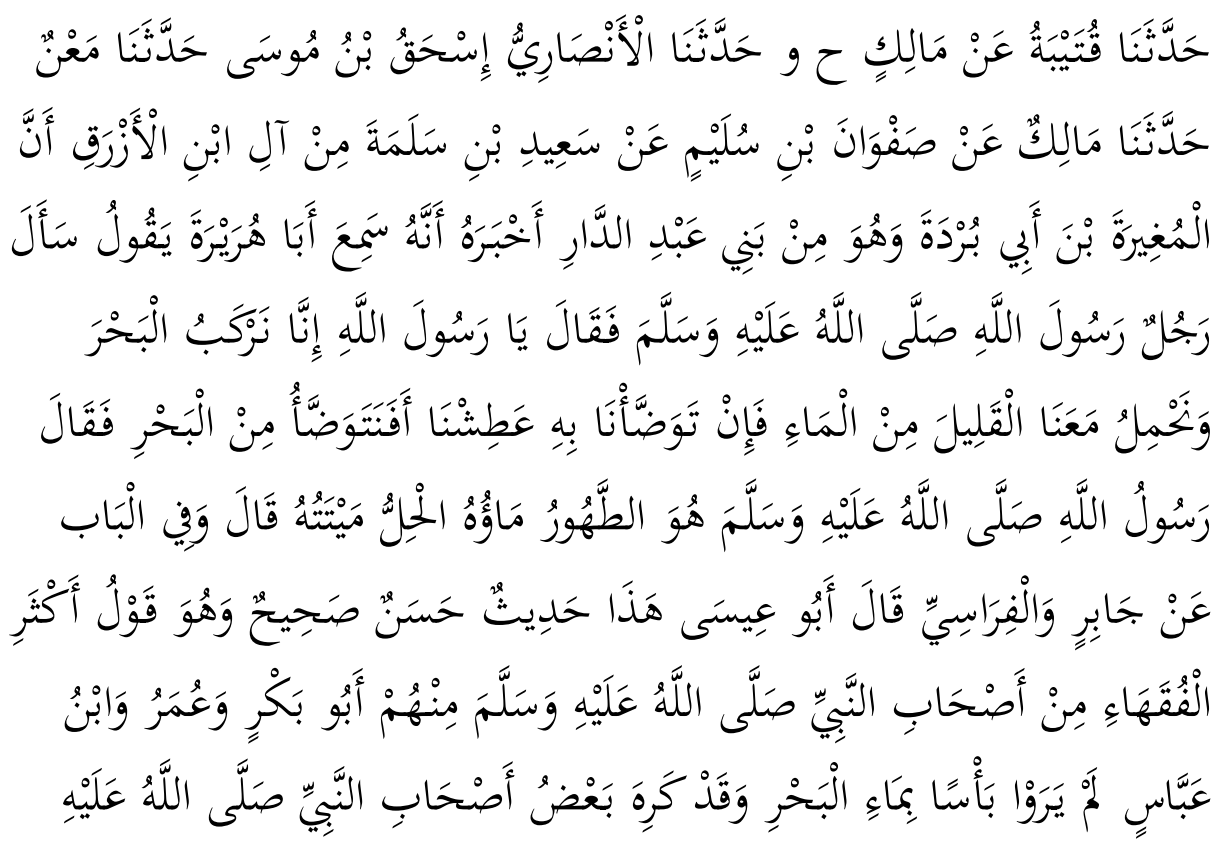

Shalih, Membahas IImu-IImu Hadis, Terj. Tim Pustaka Firdaus (Jakarta: Pustaka Firdaus, 2002), hlm.163-170, Totok Jumantoro,Kamus IImu Hadis (Jakarta:PT. Bumi Aksara, 2002), hlm. 240-242.

${ }^{16}$ Ibnu Taimiah, al-Muntaqa fi al-Ahkami asy-Syar'iyah Min Kal $\pm m$ Khair al-Bariah (Beirut: Dar Ibn al-Jauzi, 1429 H), hlm. 29.

17al-Syaukani, Nailul Authar...juz I, hlm.24. 


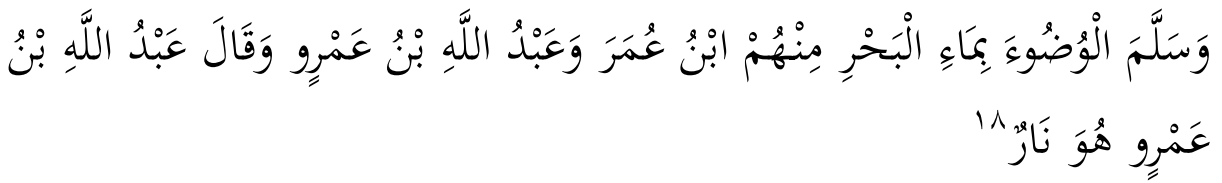

Telah menceritakan kepada kami Qutaibah dari Malik. Dan dari jalur yang lain; Telah menceritakan kepada kami Al Anshari Ishaq bin Musa berkata, telah menceritakan kepada kami Ma'n berkata, telah menceritakan kepada kami Malik dari Shafwan bin Sulaim dari Sa'id bin Salamah keluarga Ibnu Al Azraq, bahwa Al Mughirah bin Abu burdah bani Abdu Ad-Dar, mengabarkan kepadanya, bahwasanya ia mendengar Abu Hurairah berkata; bahwa seseorang bertanya kepada Nabi shallallahu 'alaihi wasallam; "Wahai Rasulullah, sesungguhnya kami mengarungi lautan dan kami hanya membawa sedikit air, jika kami gunakan air itu untuk wudlu maka kami akan kehausan. Lalu apakah kami boleh berwudlu dengan air laut?" maka Rasulullah shallallahu 'alaihi wasallam pun menjawab: "Laut itu suci airnya dan halal bangkainya." Dalam bab ini juga ada riwayat dari Jabir dan Al Firasi. Abu Isa berkata; "Hadits ini derajatnya hasan shahih, dan ini adalah pendapat yang diambil oleh kebanyakan fuqaha dari kalangan sahabat Nabi shallallahu 'alaihi wasallam.Di antaranya adalah Abu Bakar, Umar dan Ibnu Abbas.Mereka berpendapat bahwa bersuci dengan air laut itu dibolehkan. Namun ada juga sebagian sahabat Nabi shallallahu 'alaihi wasallam yang memakruhkan hal itu, di antara mereka adalah Ibnu Umar dan Abdullah bin 'Amru. Abdullah bin 'Amru berkata; "Itu adalah api."

4. Kelebihan kitab Nailul Authar

a. Menjelaskan pertentangan terhadap takhrij al-Hadis serta menjelaskan sebab terjadi pertentangannya, perbedaan lafazlafaz hadis, pendapat-pendapat yang menyebutkan sahih

${ }^{18} \mathrm{Al}-$ Hafis Muhammad bin Isa bin Syaurah at-Tirmizi, Sunan Tirmizi fil bab ma Ja a fi Ma'i al-Bahr an-Nahu Tahurun, No. 67. 
maupun daif, pendapat-pendapat para imam yang ragu, Perbedaan tersebut dibuat sesuai dengan urutannya

b. Mendeteksi maksud zahir (lafaz) hadis, pandangan pakar bahasa, dan pendapat tersebut sesuai dengan kebutuhan pembahasan yang dimaksud, serta dan pendapat yang digunakan yang berkaitan dengan hukum syara'.

c. Dalam penetapan hukum fikih, yang pertama di gunakan hadis yang berkaitan dengan pembahasa yang dimaksud, kemudian fatwa sahabat dan tabi'in, dan menjelaskan persoalan tersebut dengan berbagai mazhab (lintas Mazhab) dan ulama yang menggunakan hadis dan yang tidak menggunakan hadis, dan berhujjah dengan menjelaskan dalil yang rajah dengan tidak mengedepankan sifat fanatik dan tidak berilmu, dan mendahulukan yang dinggap benar sejauh kemampuan yang ia miliki(tidak melampaui kemampuannya) walaupun berbeda dengan pendapat jumhur.

d. Menetapkan kaedah-kaedah ushul serta menjelaskan pengaplikasian hukum furu'nya, menjelaskan tentang faidahfaidah yang bisa diambil dari hadis. ${ }^{19}$

Contoh

1. Terkadang Imam asy-Syaukani merujuk pada hadis yang belum diteliti oleh para imam hadis.

2. Dalam penentuan hukum berasal dari perawi yang telah disiqahkan atau telah didhaikkan dan hal itu merupakan pada ulama al-jarh wa at-ta'dil.

3. Jika terdapat kesilapan pada pada nama perawi, maka akan di koreksi.

4. Kalau ditemukan pendapat para ahli kalam dan ahli ilmu penambahan atau pengurangan akan ditetapkan pada nas yang asli (awal), atau di sandarkan kepada referensi dasarnya.

19/bid., hlm.11-12. 
5. Kitab yang menjadi rujukan dalam kitab Nailul Authar dari berbagai kitab: Hadis, Fikih, Bahasa, Sejarah serta Jarh wa at-Ta'dil, Yaitu:

1. Shahih al-Bukharioleh Al-Bukhari (w.256 H/870 M)

2. Shahih Muslim oleh Muslim (w. $261 \mathrm{H} / 875 \mathrm{M}$ )

3. Musnad Ahmad bin Hanbal oleh Ahmad bin Hanbal (w. 241 H/855 M)

4. Sunan Ibnu Majah oleh ibnu Majah (w. 273H/886M)

5. Sunan Abu Daud oleh Abu Daud (w. 275 H/889 M)

6. $\mathrm{Jam}^{3}$ at-Tirmizi oleh at-Tirmizi (w. $279 \mathrm{H} / 892 \mathrm{M}$ )

7. Sunan an-Nasa'i oleh an-Nasa'i (w. 303 H/ 915)

8. Sunan ad-Daruquthni oleh ad-Daruquthni (w. 385 H/ 995 M)

9. Mustadrak al-Hakim oleh al-Hakim an-Naisaburi (w. 404 H/1014 M)

10. Sunan Baihaqi oleh Ahmad bin Husain (w. 457 H/1066 M)

11. Ma'ajim ath-Thabrani (Kubra, Wasith, Syughra) oleh Sulaiman bin Ahmad (w. $360 \mathrm{H} / 971 \mathrm{M})$

12. Majmu' az-Zawa'id lil Hisyami oleh Ali bin Abi Bakr (w. 807 H/ $1405 \mathrm{M})$

13. Al-Jami' al-Kubra li as-Suyuthi oleh Abd ar-Rahman (w.911 $\mathrm{H} / 1505 \mathrm{M})$

14. Taisir al-Wusul ila Jaami' al-Usul oleh Ibn Ad-Daibi' (w. 944 H/ $1576 \mathrm{M})$

15. Syarh Shahih Muslim oleh An-Nawawi (w. 676 H/1277 M)

16. Subul as-Salam al-Mausulat ila Bulugh al-Maram oleh Ibn Amir as-San'aani (w.1182 H/1769 M)

17. Al-Mahalli oleh ibn Hazm al-Andal-si (w. $456 \mathrm{H} / 1064$ )

18. Al-Majmu' Syrh al-Muhazab oleh an-Nawawi (w. 676 H/1277 M)

19. Al-Ihkam fi Usul al-Ahkam oleh ibn Hazm al-Andalusi (w. $456 \mathrm{H}$ / 1064)

20. Fath al-Bari Syarh Sahih al-Bukharóleh ibn Hajar al-Asqalani (w. $852 \mathrm{H} / 1064 \mathrm{M})$

21. Talkhis al-Hibir oleh ibn Hajar al-Asqalani (w. 852 H/1064 M)

22. Tahzib at-Tahzib oleh ibn Hajar al-Asqalani (w. 852 H/1064 M) 
23. Taqrib at-Tahzib oleh ibn Hajar al-Asqalani (w. 852 H/1064 M)

24. Lisan al-Mizan oleh Hajar al-Asqalani (w. 852 H/1064 M)

25. Al-Bahr az-Zakkhar fi Mazahib 'Ulama'i al-Amsar oleh Ahmad bin

Yahya al-Murt«a (w. $840 \mathrm{H} / 1437 \mathrm{M}$ )

26. Asas al-Balaghah oleh az-Zamakhsyari (w. $538 \mathrm{H} / 1144 \mathrm{M})$

27. Syam al-Ul-m fi al-Lughah oleh Nusyum al-Himrari (w. 753 $\mathrm{H} / 1178 \mathrm{M})$

28. Al-'llal oleh ad-Daruquthni (w. $385 \mathrm{H} / 995 \mathrm{M}$ )

29. An-Nihayah fi Gharib al-Hadis oleh Ibn Asir $(606 \mathrm{H})$

30. As-Siqah oleh Ibn Hibban (w. 354 H/965 M)

31. Nawadir al-Usul oleh al-Hakim at-Tirmizi $(255 \mathrm{H})$

32. Az-Zahid oleh Ibn al-Mubarak (w. $181 \mathrm{H}$ )

33. Al-Musannaf oleh Ibn Abi Syaubah (w.235 H). ${ }^{20}$

\section{Penutup}

Imam asy-Syaukani dalam Kitab Nailul Authar menjelaskan pertentangan terhadap takhrij hadis perbedaan lafaz-lafaz hadis, menjelaskan maksud zahir (lafaz) hadis, dari pakar bahasa, maupun hukum syara'.

Dalam menetapkan hukum pertama melalui hadis, kemudian fatwa sahabat dan tabi'in, kemudian berdasarkan imam mazhab tanpa keberpihakan kepada satu mazhab. Penjelasan keadaan hadis, ia menjelaskan keganjilan-keganjilan, dan tidak menjelaskan secara mendetail. Pada bab-bab tertentu yang belum disebutkan oleh penulis al-Muntaqa (ibnu Taimiyah) dijelaskan beliau. Beliau tidak menjelaskan keadaan perawi (tidak menjelaskan secara detail tentang perawi) sebagaimana dalam kitab rujukannya. la melakukan hal yang sama seperti yang dilakukan oleh ibnu Taimiyah baik tentang syarh hadis, keputusan hukum, bahkan komentar-komentar.

20/bid., hlm. 14-15. 


\section{Daftar Pustaka}

Lidwa Pustala i-Software. Kitab Sembilan Imam, Software. Kitab Imam alBukhari no.187.

Lidwa Pustala i-Software. Kitab Sembilan Imam, Software. Kitab Muslim no. 3856.

Muhammad Alawi al-Maliki. IImu Ushul Hadis, terj. Adnan Qohar, Yogyakarta: Pustaka Pelajar. 2009.

Subhi bin Hasan Hallaq, Muhammad. Nailul Autharmin Asrar Muntaqa alAkhbar. Riadh: Dar Ibn Taimiyah. $1427 \mathrm{H}$.

Muhammad al-Syaukani, Muhammad bin Ali bin. Nailul Authar Syarh Muntaqa al-Akhbar. juz I, tp. Maktabah wa Mathba'ah Musthafa al-Babi al-Halab wa Auladuh. tth.

Nawir Yuslem. Ulumul Hadis, tp: PT. Mutiara Sumber Widya. 2001.

As-Shalih, Subhi. Membahas IImu-IImu Hadis, Terj. Tim Pustaka Firdaus, Jakarta: Pustaka Firdaus. 2002.

Totok Jumantoro. Kamus IImu Hadis, Jakarta: PT. Bumi Aksara. 2002. 